\title{
Assessing Accrual Accounting Reform in Greek Public Hospitals: An Empirical Investigation
}

\author{
Nikolaos Eriotis ${ }^{1}$, Filippos Stamatiadis ${ }^{2}$ and Dimitrios Vasiliou ${ }^{3}$
}

\begin{abstract}
During the last decades, several countries worldwide have introduced financial management reforms, as an important part of the New Public Management (NPM) initiative at one or more levels of government sector, by either replacing or transforming their traditional budgetary cash accounting systems towards a business-like accrual accounting concept. Following the example of this upcoming managerial trend, the Greek government introduced in 2003 the accrual basis accounting into public hospitals, as the hospital sector is one of the areas where NPM reforms have been introduced in search of higher efficiency, effectiveness and economy in service production.

The purpose of this paper is twofold. The first goal is to provide an overview of the government sector reform initiatives in Greece and to present empirical evidence regarding the adoption level of the accrual basis accounting standards in the Greek public Health sector. The second goal of the research is to investigate the impact of a range of potentially contingent factors on hospitals compliance with the accrual financial and cost accounting reform.
\end{abstract}

The present analysis is based on the results of an empirical survey that took place during 2009. For the purposes of this survey, a structured questionnaire was prepared and sent to the Chief Financial Officers (CFOs) of 132 Greek public hospitals. In particular, a linear regression model analysis was used to examine the cross-sectional differences on a number of explanatory and implementation factors of the accounting reform adoption level.

The empirical evidence reveals that the level of accrual and especially cost accounting adoption in Greek public hospitals is realized only to a limited extent. In particular, results show that the level of reform adoption is positively related to IT quality, reform related training, education level of accounting staff, and professional consultants' support. However, no significant relationship was found between the level of reform adoption and hospital size,

\footnotetext{
${ }^{1}$ Associate Professor, Department of Business and Finance, National and Kapodistrian University of Athens, 5 Stadiou St., 10562 Athens, Greece.

${ }^{2}$ Research Associate, Faculty of Management and Economics, Technological Educational Institute of Athens, 12210 Athens, Greece, e-mail: fstam23@gmail.com

${ }^{3}$ Professor, School of Social Sciences, Hellenic Open University, 18 Parodos Aristotelous St., 26 335, Patra, Greece, e-mail: vasiliou@eap.gr.
} 
reform implementation cost, CEO educational background, experience effect, and absence of management-physicians conflict relationship.

The main contribution of this study is the empirical evidence it provides on the approaches and processes used by the Government of Greece to implement accrual financial and cost accounting systems in the Greek National Health System (GNHS) and the role certain human, organizational and situational factors played in such implementations for enhancing researchers' and managers' understanding of major implementation processes and challenges as well as helping them refine models of effective implementation process and improve systems and processes on similar future projects.

Keywords: Accrual Accounting, Public Sector Accounting, Compliance, Public Hospitals, contingency factors

JEL Classification: M4, M48

\section{Introduction}

Public service organizations across the globe have been engaged in strategies of institutional, organizational and managerial change in order to cope with increasing demands for greater financial accountability, efficiency and effectiveness.

Generally, governments are implementing numerous market-based and businesslike reforms, broadly known as New Public Management (NPM), aiming at bringing the public sector in line with the private sector. NPM is used as an instrument to introduce market discipline in public bureaucracies as well as to indicate the shift in emphasis from input and process accountability towards output and results-oriented accountability. According to Christiaens et al. $(2004 ; 2007)$ the governmental accounting reform has often been the first step of government reform and that is why it can be considered as an important condition and prerequisite for the success of other consequent governmental reforms under the transformation wave of NPM, such as organizational and managerial reforms. Therefore, effective and successful implementation of the accounting reform plays an important and dominant role in the implementation and success of other NPM practices and techniques within public organizations. Without an adequate and successful implementation, all the anticipated gains, the presupposed objectives and expectations of the reform will be lost due to the fact that the new accounting system will not be able to provide relevant and accurate managerial and financial information to support it. (Christiaens and VanPeteghem, 2007).

This change of public accounting systems towards accrual basis accounting seems necessary as the traditional budgetary cash accounting system is perceived nowadays as no longer satisfactory, mainly due to the lack of presenting an accurate financial picture 
and providing useful and adequate management information to facilitate the planning and performance process (Cohen, 2007; Lapsley, 1999; Christiaens, 1999).

Within the context of NPM and following the example of numerous other countries in Europe and worldwide, the Greek public sector has encountered a number of financial accounting changes and reforms over the last ten years in order to meet the challenges that increased globalization has brought in. As a result, in 1997 the Greek government started introducing the accrual based accounting system and the double-entry bookkeeping method to some specific sectors of government activities in order to modernize its governmental accounting system. The most important examples of the Greek public sector entities where an accounting reform took place towards accrual basis accounting were: Social Securities funds (1997), Public law entities (1998), local government institutions; Municipalities, (1999) and finally public owned hospitals (2003).

In particular, in the international public sector accounting literature, the accrual accounting initiative is thought to have a number of benefits which can be grouped and summarized as follows: (i) it provides a clear picture of the total cost of government programs, activities and services provided; better measurement of costs and revenues; enhancement of control process and transparency; (ii) greater focus on outputs; focus on the long-term impact of decisions; (iii) more efficient and effective use and management of resources and greater accountability; (iv) reduction and better measurement of public expenditures; ( $\mathrm{v}$ ) better presentation of the financial position of the public sector organisations; (vi) better financial management; improvement of performance measurements and greater comparability of managerial performance between periods and organizations by calculating indicators on the basis of comprehensive and consistent financial and operational data; (vii) greater attention to assets and more complete information on public organisations' liabilities through better assets and liabilities management; (viii) better planning for future funding requirements (ix) helps with make/buy or rent/buy decisions; (x) better decisions on feasibility of providing services; (Mellett, 2002; and Olsen et al., 2001; Barrett, 1993; Evans, 1995; Pallot, 2000; Mellor, 1996; Brusca, 1997; Funnel and Cooper, 1998; Ryan, 1998; Chan, 2003; Guthrie, 1998; Jones, 2004; Barzelay, 1992; Moe, 1994; Venieris and Cohen, 2004; Cohen et al., 2007; Aucoin, 1995; Pessina and Steccolini, 2007; OECD, 2005; and International Federation of Accountants - Public Sector Committee, 2000 and 2002, pp. 7-10).

However, a considerable body of researchers call attention upon the adoption of the accrual-based accounting system by public organisations and believe that its implementation is often accompanied by a plethora of drawbacks and problems (accounting issues, and human, organizational and financial scarce resources) which hinder or delay the adoption level; for them, the transition from the cash to the accrual accounting system is not going to happen immediately and completely (Cohen et al., 2007; Christiaens, 2001; Windels and Christiaens, 2005; Guthrie, 1998; Carlin and Guthrie, 2003; Hodges and Mellett, 2003; Brusca, 1997). Thus, especially in a 
governmental context, compliance with the accrual accounting regulation can be seen as a sine qua non condition before any further successful implementation takes place.

According to Pollitt (2002) the adoption of NPM innovations can be categorized at four distinct stages: (1) disclosure, (2) Decision, (3) practices, and (4) impacts of changes. Our study focus on the practice stage in which technical NPM innovations are used by public sector organizations, including contextual and organizational factors that may influence the use of new techniques in practice.

In particular, the present research study aims at describing and comparing in an objective way the actual adoption and implementation of accruals in the Greek public hospitals by quantifying the extent of accrual financial and cost accounting implementation and testing the impact of a range of potentially contingent factors that exert an influential role on the level of accrual accounting reform adoption. This study uses quantitative research methods in order to generalize findings from previous case studies and provides empirical evidence to support the scant literature on the accounting change in public sector (i.e. Greek public hospitals).

The remainder of this paper proceeds as follows. The next section presents a short description of the Greek National Health System (GNHS) and the financial accounting reforms that took place during the last ten years. The third and fourth section present the research hypotheses and methodology applied in this study respectively. The presentation of the data analysis of the empirical research is found in section five. The paper conclusions drawn from this research as well as its limitations are set out in the final section.

\section{Accounting reform in the Greek public health sector}

Greek public hospitals have experienced a number of organizational, administrative and financial reforms since the mid-1980s in the name of improved efficiency, effectiveness, and accountability.

The Greek NHS can be characterised as a "dual-mixed" system, in which elements from both the Bismarck (increased importance of social insurance in funding health care) and the Beveridge (health care primary funded by state budget) model co-exist. The GNHS was founded in 1983 by the Greek Law 1397/83 which declared that health is a "social good" and all citizens should have the right to high quality health care. Therefore, the health care system strives to guarantee universal and free access to medical services for the entire population, based on the principles of everyone's equal treatment to health services and solidarity.

At central government level, a number of different ministries are involved in administering the supply of public health services, thus creating further inefficiency problems. The Ministry of Health and Social Cohesion (MHSC) is responsible for the provision of health care and the development and implementation on a national strategy for health policy. More specifically, the MHSC sets strategic priorities at a national level, 
defines the extent of funding for proposed activities, allocates the necessary resources (staff and material resources), proposes legislative framework changes and undertakes the implementation of laws. Nonetheless, it shares responsibilities with other Ministries. For example, responsibility for the supervision and regulation of the public insurance funds, which also administer the pension schemes, lies with the Ministry of Employment and Social Protection. This involves determining what medical benefits are covered, conditions for accessing doctors and contribution rates. The Ministry of Finance (MoF) is responsible for retrospectively subsidising the GNHS and health insurance funds, and finally, the Ministry of Development is responsible for setting drug prices (Economou and Giorno, 2009).

There are three major categories of health care providers: (1) the GNHS (public hospitals, health centres, rural surgeries and emergency rooms per hospital care) administered by the MHSC; (2) insurance funds health services with their representative units and polyclinics (mostly established within the biggest Greek insurance fund called IKA) and (3) the private sector (private hospitals, diagnostic centres, independent practices, surgeries and laboratories).

Regarding secondary hospital health care provision, approximately $75 \%$ of hospital beds are in the public sector (67\% in the GNHS) and $25 \%$ in the private sector. The average bed capacity for public hospitals is 233 beds and for private hospitals only 55 . Health care services, in the public sector, (mainly Secondary and tertiary health care) are provided in 132 general and specialized public hospitals which operate within the NHS. The NHS public owned hospitals have a total capacity of 34.134 beds. Moreover, 195 Health Centres operate in rural areas. Rural Surgeries, attached to the Health Centres, provide primary health care services. The Health Centres provide also emergency services, short hospitalisation and follow up of recovering patients, dental treatment, family planning services, vaccinations, and health education (Economou and Giorno, 2009).

Traditionally, Greek governmental budgeting and accounting system at all three levels of public governance -central, regional and local- is regulated by law and not by an independent standard-setting professional body and it is still based upon the cash principle of accounting.

Similarly, the governmental accounting regulations applying to Greek public hospitals - which date back to 1974 with the legislative decree 496/74 - are also based on an old budgetary and single-entry book-keeping accounting system that still has a primarily cash basis accounting approach. Thus the form of accounting that exists in public hospitals is that of budgeting on a cash basis.

More specifically, the main purpose and concern of the public hospitals' budgetary cash accounting system was to recognize transactions and other events only when cash was received or paid, to record them in the authorised budgets, to be driven by budgetary principles, and finally to control the execution of the budget approved by the 
governmental decision makers. On the other hand, little attention was given to providing a complete picture of the financial position and financial performance of public hospitals. Under this approach, calculations for decision making seldom take place, and focus of the budget evaluation process lies heavily on the cost side, whereas the income side is underestimated. In other words, focus lies on expenditure control and record keeping, and no attention is paid in performance evaluation and feedback. Consequently, no action is taken to tie performance measures, and thus accounting information is not used to guide decision making. According to Mossialos et al., (2005): "Resource allocation mechanisms of public hospitals in Greece are historical and political with no relation to performance or output; therefore providers have little incentive to improve their productivity".

The Greek management literature has long pointed out the need for reforming this budgetary cash accounting system in the health public sector and has indeed supported the switch to accrual accounting (Ballas and Tsoukas, 2004; Venieris, Cohen, and Sykianakis, 2003). Traditional budgetary cash accounting has long been viewed as 'outdated', no longer satisfactory and making a significant contribution to the inefficiency and ineffectiveness of the Greek public sector because it does not permit the disclosure of the full picture of the economic activity and financial position of the public hospitals (Lüder and Jones; 2003).

The initial efforts of introducing the accrual basis of accounting in public hospitals in Greece commenced in 1997 under the Law 2519/97. This Law presented for the first time the government's attempt and intention to introduce a double-entry bookkeeping accounting system and cost management methodologies in public hospitals based on the accrual basis.

For this purpose, the development and preparation of an Official Health Sector Accounting Plan (HSAP) aimed at developing the conceptual framework for accrual accounting in public hospitals, was assigned by the Ministry of Economy and Finance to the national Council of Accounting (ESYL) and to the Chamber of Finance (OEE).

The HSAP mainly included broad guidelines regarding principles for accrual basis accounting implementation, similar to those applied to the private sector, the charts of accounts, asset classification, examples of journal entries, templates of the layout and the content of the published financial statements (i.e. balance sheet, income statement, The Statement of Income Distribution, Budget report and Actual report) and some suggested financial and costing ratios (Venieris and Cohen, 2004).

Furthermore, a pilot implementation project, under the experimentation clauses of the HSAP, commenced in 1999 in order to test the suitability of the new accounting system and its readiness for full implementation. Five Public owned hospitals that would implement the HSAP as pioneers were selected.

The governmental efforts to reform the accounting system of the health sector escalated in 2003, after taking the pilot implementation experiences into account and 
making the necessary modification and amendments to the HSAP, when a law, the Presidential Decree 146/03 (P.D. 146/03), was passed.

The P.D. 146/03 enforced the mandatory adoption of the new accounting system, based on accrual basis, on all the public hospitals that are part of the Greek NHS and established the necessary guidelines and accounting standards for financial reporting purposes. However, the previous traditional budgetary cash accounting system was not abandoned but, instead, the public hospitals just added the accrual accounting system separately and most of the budgetary accounting principles were maintained (Christiaens, 2001). The new accounting framework of the P.D. 146/03 defined two accounting systems that should work simultaneously under three independent accounting cycles; the financial accounting cycle, the budgeting cycle and the cost accounting cycle, within the same general ledger and while each one would still retain its autonomy. The legislator believed that the solution of introducing this combined approach for accrual accounting and double-entry budgetary cash accounting through two separate accounting systems should be the most beneficial in order to reap the best of the two accounting systems, as each one has its own strengths and weaknesses (Venieris and Cohen, 2004). The financial accounting system aims at reporting the financial position and the yearly profit and loss of hospitals, the budgeting system aims at authorizing and controlling the public spending (Christiaens and Rommel, 2008) and the cost accounting system aims at calculating the health services' full cost by using the accounting data of the financial accounting cycle (accrual accounting) and processing them within a rather complicated framework of double entry journal entries (Venieris and Cohen, 2004).

The P.D. 146/03 pointed out that the deadline for the implementation of accrual financial accounting in public hospitals was the $1^{\text {st }}$ of January 2004, while the deadline for cost accounting introduction was the $1^{\text {st }}$ of January 2005.

\section{Research questions and hypotheses development}

Although the NPM reform, regarding the implementation of accounting standards on an accrual basis, is coercively imposed by the P.D. 146/2003 it is not sure that its implementation will take place immediately and completely (Chriastiaens et al., 2004). Thus, the first objective of this study is to identify major areas of non-compliance with the accounting reform. This leads to the first research question:

RQ1: At what extent do public hospitals comply with the new accounting standards set out in the PD 146/03?

A second objective is to explain cross-sectional differences in the adoption and implementation of accrual accounting by identifying several characteristics of public hospitals that play an influential role to the level of accounting reform adoption. This leads to the second research question: 
RQ2: Can the cross-sectional differences in the level of compliance with the accrual accounting legislation be associated on organizational capability factors derived from previous and current research?

Based in previous studies, (see for example, Ouda, 2004; Venieris et al., 2003; Christianens, 1999; Windels and Christiaens, 2005; Cardinaels et al., 2004; Arnaboldi and Lapsley, 2003) a number of related hypotheses can be formulated:

\subsection{Education level of the accounting staff (EDUC)}

Concerning the personnel's educational level, the literature suggests that, when educated to a higher level, an organization's staff is expected to appreciate the usefulness and use of new accounting techniques more and thus to promote its implementation in governmental organizations (Ouda, 2004; OECD, 2003; Venieris et al., 2003). According to Windels and Christiaens (2004) the general level of education of the executives and their staff has positively affected the level of NPM reform adoption in Flemish local governments. Furthermore, Stamatiadis (2009) found that the educational level of accounting staff is positively related to the user's perceived satisfaction level of financial accrual accounting system adoption in Greek public hospitals. Based on the above discussion the following hypothesis is formulated:

H1: The level of accounting reform adoption is positively associated with education level of accounting department personnel.

\subsection{Training (TRAIN)}

Prior studies support this hypothesis that adequate training has a positive influential effect on the successful adoption of cost accounting systems, as understanding of how to design, implement and use these systems is enhanced (Krumwiede 1998; Shields 1995). Similarly, public sector studies point out that the transition from cash based accounting to accrual and cost accounting requires significant training costs (see for e.g. Brusca, 1997). According to Ouda (2004), the fact that employees are neither sufficiently informed of the direction of the change nor empowered to contribute to the process, constitutes one typical reason for which many accounting changes in the public sector have failed in the past. Therefore, the introduction of a new accounting system in the public sector requires an overall training strategy to disseminate objectives and prerequisites of the change process, to clarify potential misunderstandings, to convey a common understanding of the key principles of the accounting changes and to convince for the potential benefits of the new system. In other words, training has to provide a mechanism for employees to understand, accept, and feel comfortable with the NPM ideas and instruments, and prevents employees from feeling pressured or overwhelmed by the implementation 
process (Cavalluzzo and Ittner, 2004). If training resources are insufficient, then normal development procedures may not be undertaken, increasing the risk of failure (McGowan and Klammer, 1997; Venieris et al., 2003). Based on the above discussion the following hypothesis is formulated:

$\mathrm{H} 2$ : The level of accounting reform adoption is positively associated with the level of reform-related training of the accounting staff.

\subsection{The quality of information technology (ITQUAL)}

Consistent with information system and management accounting change models, surveys in the private sector, report that information systems' inefficiencies and data limitations, such as the inability of existing information systems to provide reliable, accurate, and up-to-date data in a cost effective manner, represent a major impediment to management accounting systems implementation and use (Krumwiede, 1998; McGowan and Klammer, 1997; Kwon and Zmud, 1987; Anderson, 1995; Shields and Young, 1989). Krumwiede (1998), for example, suggests that organizations with more advanced information technology may be more able to implement new management accounting systems than organizations with less sophisticated information systems because of lower processing and measurement costs. Enterprise Resource Planning (ERP) systems have commonly been promoted as an appropriate technical platform. According to Reeve, 1995 and Anderson, 1995 (cited in Al-Omiri and Drury, 2007) organizations with ERP systems can integrate business processes across functional areas and accumulate operational data needed for resource and activity analysis from multiple sources in one central database. This can streamline processes, reduce processing time, and increase control within organizations.

Field studies and surveys from the public sector report similar results (GAO, 1997a; Jones, 1993; OECD, 2003; Ouda, 2004; Arnaboldi and Lapsley 2003; Guthrie, 1998; Hepworth, 2003; Scapens and Jazayeri, 2003). These studies suggest that advanced information technology will be required to facilitate and support the introduction of accrual accounting in the public sector. As a result, high existing quality in the organization's information systems should be considered as a necessary prerequisite of successful implementation of NPM initiatives (Ouda, 2004). These arguments lead to the formulation of the following hypothesis:

H3: The level of accounting reform adoption is positively associated with the level of existing information technology quality.

\subsection{Professional support from consultants (CONSUL)}

There is a large amount of governmental accounting literature which describes management consultants as epistemic communities of specialized knowledge and expertise - their assistance and hands on support is deemed as necessary in the current 
reforming climate of NPM. Thus, management consultants have been identified as key levers in the process of changing management practices in the public sector and facilitating the implementation process as a technical implementation support but also as a "knowledge source" (Arnaboldi and Lapsley, 2003; Hood, 1995; Lapsley and Oldfield, 2001; Laughlin and Pallot, 1998; Ouda, 2004). In Christiaens' study (1999) the assistance of professional consultants is the most important positive explanatory factor highlighting compliance differences among Flemish municipalities. Therefore, hospitals employing management consultants in their operations are expected to exhibit a higher level of reform adoption. Hence, the following hypothesis is formulated:

H4: The level of accounting reform adoption is positively associated with Professional support of management consultants' use.

\subsection{Long term experience in accrual accounting (EXPER)}

Hospitals with long term experience in accrual accounting are assumed to have gathered all the relevant necessary experience and be familiar with the accrual concept by now. These hospitals are assumed to have resolved most of the accounting and implementation problems and shortcomings emerged during the accrual accounting system installation and progressively overcome most of these difficulties as they are getting familiarized with it. Thus, it could be expected that hospitals with long-term experience in implementing accrual accounting will attain a superior level of accounting compliance (Christianens, 1999). Therefore, the following hypothesis is formulated:

H5: The level of accounting reform adoption is positively associated with hospitals longterm experience in accrual accounting.

\subsection{Accounting reform implementation cost (COST)}

Prior studies on public sector reform have reported that the high implementation cost of a new accounting system (e.g., staff training, Information Systems changes, consultants' fees etc), even if it is mandatory, can considerably deter or delay the whole adoption process and its anticipated consequences (Lawson, 2005; Udpa, 1996; Canby, 1995; Ouda, 2004). Because an accounting change can be rejected if it is too costly, although it is coercively enforced, the following hypothesis is formulated:

H6: The level of accounting reform adoption is negatively associated with the cost of its implementation.

\subsection{CEO educational background (CEOEDUC)}

Results of prior organizational change studies suggest that CEOs with a predominant administrative background may be more likely to advocate and support administrative innovations that promise to further managerial efficiency and 
effectiveness, whereas CEOs with a predominant clinical background would be more likely to be interested in the adoption of innovations in the core technology (e.g., new surgical procedures, new drugs, new equipments etc) rather than administration (kimberely and Evanisko, 1981; Emsley et al., 2006; Finkelstein and Hambrick, 1996; Naranjo-Gil, Hartmann, 2007).

Based on the above discussion the assumption is made that Managers with an administrative/business-oriented educational background against clinical educational background would rely more on formal and hierarchical forms of management and thus would be more motivated to adopt accrual accounting systems and reap the expected benefits of the more accurate, reliable and relevant accounting information they provide for achieving efficient decision-making process, to disseminate objectives and prerequisites of the change process, to clarify potential misunderstandings, to convey a common understanding of the key principles of the accounting changes, and to convince users for the potential benefits of the new system. Therefore, the following hypothesis is formulated:

H7: The level of accounting reform adoption is positively associated with CEOs business-oriented educational background.

\subsection{Management-physician relationship (CONFLICT)}

Burns and Scapens (2000) suggest that in order to successfully implement changes in an organisation a thorough examination of the identification of potential organisational conflicts is needed. The various interest groups that are involved in a strategic change process are likely to have different goals, values and problem solving styles and different rationalities. According to Venieris et al, 2003 conflicts may arise from the existence of different and opposing rationalities between actors, those that promote change and those who resist it in fear of losing privileges. Consequently, the success level of reform adoption in public organizations can be hampered because of perceived incompatibility with the needs and values of different subculture groupings (Markus and Pfeffer, 1983; and Scapens and Roberts, 1993).

This is the case in hospitals where administrative activities (including finance and accounting practices) are loosely-coupled with clinical (core) activities (i.e. the treatment of patients) (Abernethy and Vagnoni, 2004; Coombs, 1987; Kurunmaki et al., 2003; Lapsley, 2001; Pettersen, 1999). Additionally, the study of health sector in Norway by Pettersen (1999) reports the existence of different professional cultures between hospital management staff and physicians. Pettersen (1999, pp. 392) concludes that:

"Hospitals are professional bureaucracies with very strong and specific norms which control medical actions. These norms are very different from ideas of accounting norms, which are supposed to control accounting action. In such situation, two different cultures are inside hospitals, the clinical and the administrative cultures. The clinical world follows the logic of appropriateness, 
whereas the administrative world's decisions are based on the logic of consequentiality. In such situation, organizational learning and change can be a very difficult process".

In the GNHS the hospital is operating as a professional bureaucratic organization under the structure of which physicians constitute the dominant operating core, whereas accountants and the rest of administrative staff are considered as secondary; thus, overall management style seems to favour clinical to financial objectives. In this context, physicians often perceive and interpret management and accounting reform initiatives in quite a different way from management staff because of different norms and training and diverse purposes (Ballas and Tsoukas, 2004). Thus, implementation of the accrual-based accounting systems may be achieved more easily in hospitals where the relationship between management and physicians portrayed as an area with minimum conflict. In this sense the following hypothesis is formulated in order to test the intra-organizational power relationships:

H8: The level of accounting reform adoption is positively associated with the absence management-physician conflict.

\subsection{Size of the Hospital (SIZE)}

The size-effect variable of the public organization in question has also been incorporated in other previous governmental accounting studies as an important factor influencing the level of management and cost accounting systems adoption. However, the impact of the size variable on the level of compliance is not clear. In particular, some of the previous studies noted a positive relation between the organization size and the level of businesslike management instruments adoption (Christiaens, 1999; 2001; Cardinaels et al., 2004; Krumwiede, 1998; Innes and Mitchell, 1995; Bjornenak, 1997). However, there are studies which found no significant relationship (Evans and Patton, 1983; Robbins and Austin, 1986) and even studies where a negative relationship is observed (Cohen et al., 2007; Lüder, 1992).

This study assumes that larger hospitals, in terms of bed capacity, are more likely to have implemented an accrual accounting system to a greater extent. A possible reason for this is that larger organizations have relatively greater access to resources to introduce and implement management systems and techniques. Another reason would be that as organizations become larger, the need to handle greater quantity and quality of information increases to a point where the introduction of management systems deems necessary. For these reasons the following hypothesis is formulated:

H9: The level of accounting reform adoption is positively associated with hospital size. 


\section{Research Method}

\subsection{Sample characteristics and data collection}

In order to collect the necessary data, a survey using questionnaires was conducted during 2009 in all Greek public hospitals. The questionnaire was sent by electronic mail (e-mail) and facsimile (fax) to 132 Chief Financial Officers (CFOs) of public hospitals. The main criterion for the selection of CFOs as key informants in this study was their expected knowledge about the adoption and implementation of the new accrual accounting system within their organizations. Thus, we believe that the answers are reliable. Eventually, out of 132 distributed questionnaires, 94 usable questionnaires were returned, yielding a total response rate of $71.21 \%$.

Prior to the presentation of the research findings, there will be a reference to the demographic characteristics of the public hospitals included in the sample. Table 1 (in Appendix) shows the hospitals' financial, geographical and organizational characteristics, such as geographic region, financial turnover, number of employees, number of beds and type of hospital.

In order to minimize the chance that the reported results differ between respondents and non-respondents a nonparametric, one-sample Chi-square test was performed to test respectively (a) whether the distribution of the 132 hospitals in the response $(n=94)$ or non-response $(n=38)$ was independent of two demographic characteristics: administrative region and size, and (b) whether early and late respondents provided significantly different responses (Naranjo-Gil and Hartmann, 2007). The Chi-square statistic indicated no significant differences in both the demographic characteristics (administrative region: $\chi^{2}=0.683 ; \mathrm{df}=6 ; \mathrm{p}=0.995$, and size: $\left.\chi^{2}=0.787 ; \mathrm{df}=2 ; \mathrm{p}=0.675\right)$ and in the means of responses for non-respondents and early versus late respondents respectively (administrative region: $\chi^{2}=3.395 ; \mathrm{df}=6 ; \mathrm{p}=0.758$, and size: $\chi^{2}=0.379 ; \mathrm{df}=2 ; \mathrm{p}=0.827$ ). Accordingly, it can be concluded that non-response bias is unlikely to be a threat to the conclusions based on the responses received.

In terms of size the sample counted $41.4 \%$ small facilities with less then 200 beds, $32.9 \%$ medium-sized hospitals with 200-499 beds and 25.5\% large hospitals with over 500 beds.

\subsection{Measurement of the variables}

\section{Dependent variable}

In order to quantify and measure the extent of reform adoption, the indexmethodology is used to capture the diverse set of reform into an easily understood indicator. This approach has proven to be a useful method for this as it permits a general research of many aspects of reform and it has been used in a number of previous studies 
(Robbins and Austin, 1986; Ingram, 1984; Giroux, 1989; Cheng, 1992; Coy et al., 1994; Christiaens, 1999; Ryan et al., 2002; Cohen and Kaimenakis, 2007). In particular, the level of regulatory compliance variable "COMPLIANCE" was measured using an index developed for the purpose of this study and mainly based on the accounting grounds and characteristics established by the P.D. 146/03. This index comprises of 16 elements with each one measured dichotomously. Respondents were asked to respond "yes" (value =1) if in compliance with the relevant accounting standard and "no" (value $=0$ ) if not. The overall compliance index was calculated for every hospital as the sum of its scores in all dichotomous variables; a hospital's index would take the value of 16 if it conformed to all accounting standards. The elements that were used in order to construct the compliance index are presented in Table 2 (in Appendix).

\section{Independent variable measurement}

Objective data was used for the "CEOEDUC", "EDUC", "SIZE", and "EXPER" variables. Learning Experience effect (EXPER) is measured using the number of years passed of hospital first accrual based financial statements issuance year. The CEO educational background (CEOEDUC) is measured using the years of business-oriented education to the total number of education years ${ }^{1}$. The size variable was measured using the natural logarithm number of beds. Regarding the general level of accounting staff education (EDUC), a compound average level of finished studies (master, bachelor and secondary level) was used ${ }^{2}$. A dichotomous variable named COST was used in order to determine the level of the cost implementing and adopting accrual accounting as a percentage of the annual hospital budget. In cases where a hospital believed that the implementation cost was high the variable was assigned a value of 1 , and 0 if it is low.

The other four independent variables, "CONFLICT", "CONSUL", "ITQUAL", and "TRAIN", required the use of perceptive measures and thus multi-question Likert-type five point scales (where $1=$ strongly disagree and $5=$ strongly agree) were used to derive composite scores for each factor. All of the measures were based on previous literature. Multiple items were preferred because they captured more of a construct's multidimensionality than single items (Foster and Swenson, 1997; Cardinaels et al., 2004; A1-

\footnotetext{
${ }^{1}$ In particular, this indicator is measured by the following formula: Business-oriented educational background $=(\mathrm{UD}+\mathrm{PD}+\mathrm{T}) /($ total number of education years $)$ in which UD for years of undergraduate degree on business oriented education, PD stands for years of postgraduate degree on business oriented education, and $\mathrm{T}$ for years of training seminars and special courses on business oriented education.

${ }^{2}$ EDUC is measured using the following ratio: $(1 * \mathrm{PD}+0.5 * \mathrm{UD}+0 * \mathrm{SD}) /(\mathrm{PD}+\mathrm{UD}+\mathrm{SD})$ in which PD stands for the percentage of accounting staff holding a postgraduate degree, UD for the percentage of staff holding an undergraduate degree SD for the percentage of staff holding secondary education degree. The above approach is used in the present survey, in order to gain comparable scores over the hospitals.
} 
Omiri and Drury, 2007; Krumwiede, 1998). The descriptive statistics of the independent variables in the study are presented in Table 3 (in Appendix).

The resulting composite factor scores are computed using mean standardized responses, having a mean of zero and a standard deviation of one, to the survey questions loading greater than $0.40^{3}$ on the respective factors with eigenvalues in excess of one. The construct validity and reliability for the multi-item variables were assessed by using a principal component analysis and Cronbach coefficient alphas ${ }^{4}$ respectively. Based on this analysis, the factors appear to be reliable and reasonably valid. The results of the factor analysis for the four composite variables are presented in Table 4 (in Appendix).

Finally, Table 5 (in Appendix) also presents a Pearson Correlation matrix for the independent variables. None of the Pearson Rank correlation coefficients are high thus suggesting that multi-collinearity is not an issue. Lewis-Beck (1990) (cited in Pavlatos and Paggios, 2009) reported that intercorrelations need to be 0.8 or above before they are of any concern.

\section{Survey results}

\subsection{Main Results of the compliance Index}

The elements related to the accounting compliance index are shown in Table 6 (in Appendix). The total extent of compliance scores range from a high of 93.75 per cent of the maximum possible score to a low of 6.25 per cent. On average, each organization reported a 50.99 per cent of compliance with the prescribed accounting reform (Table 2). Thus, in general public hospitals present a moderate to low compliance score to P.D.146 requirements after 6 years of its inception.

Moreover, the major non-compliance areas can be observed in the area of services costing as the worst performers are the "Accurate and updated costing system", "Proper inventory management", "Definition of cost centres/pools/ objects", and "Accurate calculation of Fixed and variable cost".

These findings are consistent with Comerford and Abernethy (1999) and Hill (2000) that supported the low adoption level of cost accounting systems in hospitals. They reported that hospitals traditionally had little incentive or demand for cost accounting systems to be used as a management control tool. Hospitals primarily reported to external funding authorities, such as the government, and therefore only served as external reporting factors.

In the Greek context, one possible explanation for these findings could be that the accounting reform was mostly dedicated with extensive guidelines to accrual financial

\footnotetext{
${ }^{3}$ This is in line with Hair et al. (1998) who considered items that display factor loadings of .40 and above as important

${ }^{4}$ All factors have coefficient alphas above the minimum level of 0.5 suggested by Hair et al. (1998) Indicating that are all reliable and reasonably valid.
} 
accounting rather than cost accounting (e.g., no guidelines on how the corresponding cost of a department should be calculated). Thus, from an Institutional theory perspective, in order to gain legitimacy and financial security by conforming to external expectations and to appear rational, and efficient to their constituents regarding the new accounting practises, hospitals have to focus more towards accrual financial accounting compliance.

Additionally, the reformed accounting legislation neither identified explicitly the outputs nor had intention of connecting the cost of outputs with the reimbursement received by the hospital for the services offered to patients. Consequently, no incentive was given to hospitals to control their costs as they will continue to receive their subsidies (funding process) irrelevant of their performance and financial results. In particular, the current reimbursement system applied in the GNHS could be classified as a retrospective per-diem reimbursement. This payment method, in which the hospital's own costs are reimbursed ex post at a fixed rate per day of hospitalization, eventually provides no incentives to public hospitals to stimulate efficiency and to economize; hospitals are reimbursed for extra production and not for cost efficiency initiatives. Under per-diem reimbursement hospitals prefer to keep the patients in the hospital as along as they can, in order to allow additional revenues to be generated.

Finally, another reason why hospitals have failed to fully comply with the reformed accounting principles may be the lack of an effective enforcement mechanism to actually mobilize the implementation process with budgetary cutbacks or explicit financial restrictions and penalties in case of no compliance. Hence, although fines and penalties have been established by the legislator in the P.D. 146/03 in case of non-compliance with the adoption timetables no such action has been taken yet. This finding is consistent with the argument of Berry and Jacobs (1981), (cited in Cohen et al., 2007), that the lack of an effective enforcement system is a leading reason of non-compliance.

\subsection{Factors affecting the compliance level}

In order to test the level of accounting reform in public the following model was applied:

$$
\begin{aligned}
& Y=a+b_{1} \text { EDUC }+b_{2} \text { TRAIN }+b_{3} \text { ITQUAL }+b_{4} \text { CONSUL }+b_{5} \text { EXPER }+b_{6} C O S T+b_{7} \\
& \text { CEOEDUC }+b_{8} \text { CONFLICT }+b_{9} \text { SIZE }+e
\end{aligned}
$$

Where $\mathrm{Y}$ : is a variable measuring the level of compliance with the accrual financial and cost accounting based on P.D. 146/03 guidelines. Moreover, the above model contains 9 independent variables. In order to examine the associations proposed in hypotheses H1 through $\mathrm{H} 9$ in Section 3 a multivariate regression analysis was used because the univariate tests provide valuable information regarding a large number of variables over a sample and their results are informative but there is the question of whether the 
association is a direct association or whether there is a joint correlation with a third or fourth variable.

The results of the Ordinary Least Squares (OLS) regression are presented in Table 7 (in Appendix).

The observed F-statistic of the regression is 17.040 and significant at alpha $=0.000$ which points at an acceptable goodness-of-fit. The validity threat of multicollinearity is examined with a Pearson correlation test and by calculating the tolerance and variance inflation factors (VIF) for all the independent variables (see the two final columns of the table). No indication of multicollinearity is found between the different variables ${ }^{5}$. The adjusted $\mathrm{R}^{2}$ explains 60.8 percent of the variation for compliance level.

The results presented in Table 7 indicate that among the nine variables which were tested for associations on the level of the accounting reform, four are statistically significant: the level of specific training $(\mathrm{p}<0.1)$, IT existing quality $(\mathrm{p}<0.05)$, education level of accounting department staff $(p<0.01)$, and professional support from consultants $(\mathrm{p}<0.01)$, were the most significant in statistical terms. On the other hand, the hospital size ${ }^{6}$, the years of accrual accounting experience, the CEO educational background, the absence of management-physicians conflict, and level of implementation and adoption cost do not exhibit a statistically significant influence on accounting reform compliance level. Thus, we summarize that statistical analysis showed that only H1, H2, H3, and H4 hypotheses are supported, while H5, H6, H7 and H9 are not supported by the data

\section{Conclusion}

\subsection{Research findings}

This present research study is not set up to explain the reasons of the accounting reform in public hospitals, nor is it an analysis or an appraisal of the impulses or incentives behind the reform. It aims at exploring, describing and comparing in an objective way the actual adoption and implementation of accrual financial and cost accounting practices in public hospitals. This can only be done by analyzing features of organisations that succeed in complying with the reform requirements and determining the impact on the level of accounting reform adoption of certain factors cited in previous studies (see for example, Ouda, 2004; Venieris et al., 2003; Christianens, 1999; Windels and Christiaens, 2005; Cardinaels et al., 2004; Arnaboldi and Lapsley 2003).

\footnotetext{
${ }^{5}$ The Variance Inflation Factors (VIF) of the variables which comprise our model are well below the generally accepted critical threshold of 10 , ranging between 1.08 and 2.13 , and tolerances are of more than 0.20 , indications that allude a potential severe problem of multi-collinearity (Kutner et al., 2004; Hair, 1998).

${ }^{6}$ In order to examine the robustness of our results, we included number of employees in our analysis instead of bed number as an alternative proxy for hospital size. Results remain similar.
} 
Under this research approach, the present research results indicate that the level of accounting reform adoption in public hospitals is realized only to a limited extent (i.e., $50.99 \%$ score), especially on cost accounting aspects of the reform. The relatively higher compliance index scores of financial accounting system aspects compared to the lower compliance score of the cost accounting system aspects indicate that hospitals' management focused more to some specific reform aspects than others maybe due to different institutional pressures.

Regarding the second research question, the data suggests that public hospitals experience implementation difficulties because of resources and operational capacity considerations (i.e., lack of organizational, technological and human resources) in complying with the regulatory requirements. In particular, the cross-sectional differences in the level of adoption reveal that there are certainly some significant enablers and /or constraints in the process of organizational change. In particular, this study reveals that organizational and technical capability aspects for action, such as the support of consultants, IT existing quality, education level of accounting department staff, and the level of specific training, are important positive factors in explaining the alternative implementation scenarios adopted by different public hospitals. On the other hand, other contextual factors, such as larger hospitals, familiarization with accrual accounting, CEOs with business oriented educational background, perceived implementation cost, and optimal relationship of professional groups within hospitals, do not exhibit any significant association with the accounting reform adoption level.

\subsection{Limitations and suggestions for future research}

The study findings are subject to a number of limitations. Cross-sectional studies as this work presented here can establish associations, but not causality. Another factor that may affect these results is the noisiness of the measures. A mail survey prevents an assessment of the survey respondent's actual knowledge of the accrual accounting, although the surveys were mailed to Chief Financial Officers. In particular, although tests were performed to look for evidence of non-response bias, there is no way to directly test whether the non-respondents $(n=38)$ are systematically different to the respondents $(n=94)$. Furthermore, the data regarding the compliance index is based on the respondents' opinions (perceptual measures) and not on objective measures in the absence of official statistics which could offer a clearer picture with regards to the impact of the explanatory and implementation factors discussed throughout this paper.

Future research may further examine the relation between level of accounting reform adoption and wider social and institutional forces that surround it as well as consider incorporating other important contextual variables that have been omitted from other studies and are likely to influence the compliance level. The most notable omitted variables are: the number of services variant as a proxy measure of hospital complexity; type of hospital (general or specialized); location of hospital (urban or rural); satisfaction 
of the cash accounting system. In addition, the importance of inter-organizational variables such as support from external audit and central and local political support must not be underestimated.

Despite these limitations, this study contributes to the literature of accrual accounting reforms in public sector organizations by providing, to our knowledge, the first large cross-sectional assessment of accrual and cost accounting system implementation in Greek public hospitals. In particularly, it adopts a contingency approach and uses empirical analysis to identify the influence of specific contingent factors on the level of compliance with accruals accounting in order to enhance researchers' and government managers' understanding of major implementation processes and challenges encountered in a complex political environment, such as the Greek context. Enhanced understanding can help them build and refine models of effective implementation processes on similar future projects of other accounting and systems reforms, as they can learn from the experiences of others.

\section{References}

Abernethy M., Vagnoni E., 2004, 'Power organization design and managerial behaviour', Accounting, Organizations and Society, 29, pp. 207-225.

Al-Omiri, M., and Drury, C., 2007, 'A survey of factors influencing the choice of product costing systems in UK organisations', Management Accounting Research, pp. 399-424.

Arnaboldi, M., Lapsley, I., 2003, 'Activity Based Costing, and the transformation of Local Government', Public Management Review, 5, 3, pp. 345-375.

Ballas, A. and Tsoukas, H., 2004, 'Accounting for the Lack of Accounting: The Case of the Greek National Health System', Human Relations, 57, 6, pp. 661-690.

Bjornenak, T., 1997, 'Diffusion and accounting: the case of ABC in Norway', Management Accounting Research, 8, 3, pp. 3-14.

Brusca, Alijarde, I., 1997, 'The Usefulness of Financial Reporting in Spanish Local Governments', Financial Accountability \& Management, 13, 1, pp. 17-34.

Burns, J. and Scapens, R.W., 2000, 'Conceptualizing management accounting change: an institutional framework', Management Accounting Research, 11, 1, pp. 3-25.

Canby IV, J., 1995, 'Applying activity-based costing to healthcare settings', Healthcare Financial Management, 49, 2, pp. 50-55.

Cardinaels. E., Roodhooft. F. and Van Herck., G., 2004, 'Drivers of cost system development in hospitals: results of a survey', Health Policy, 69, pp. 239-252.

Carlin, T. and Guthrie, J., 2003, 'Accrual Output Based Budgeting Systems in Australia: The Rhetoric-reality Gap', Public Management Review, 5, 2, pp. 145-62. 
Cavalluzo, K., Ittner, C., 2004, 'Implementing performance measurement innovations: evidence from government', Accounting, Organizations and Society, 29, pp. 243267

Chan, J., 2003, 'Government accounting: an assessment of theory, purposes and standards', Public Money \& Management, 23, 1, pp. 13-20.

Cheng, R.H., 1992, 'An empirical analysis of theories on factors influencing State government accounting disclosure', Journal of Accountancy and Public Policy, 11, 1, pp. 1-42.

Christiaens, J., 1999, 'Financial Accounting Reform in Flemish Municipalities: An Empirical Investigation', Financial Accountability \& Management, 15, 1, pp. 2140.

Christiaens, J., 2001, 'Converging New Public Management Reforms and Diverging Accounting Practices in Flemish Local Governments', Financial Accountability \& Management, 17, 2, pp. 153-70.

Christiaens, J. and E. de Wielemaker, 2003, 'Financial Accounting Reform in Flemish Universities: An Empirical Study of the Implementation', Financial Accountability \& Management, 19, 2, pp. 185-204.

Christiaens, J. and Vanhee, C., 2001, Innovations in governmental accounting systems: the concept of a 'mega general ledger' in Belgian provinces, Research working paper Ugent, nr. 01/113, 27.

Christiaens, J. and Vanpeteghem, V., 2003, 'Governmental Accounting Reform: Evolution of the Implementation in Flemish Municipalities', Financial Accountability \& Management, 23, 4, pp. 375-399.

Christiaens, J. and Rommel, J., 2008, 'Accrual Accounting Reforms: Only in businesslike (parts of) governments', Financial Accountability \& Management, 24, 1, pp. 59-75.

Coombs, R.W., 1987, 'Accounting for the control of Doctors: Management Information Systems in hospitals', Accounting, Organizations and Society, 12, 4, pp. 389-404.

Cohen, S., Kaimenaki E. and Zorgios, Y., 2007, 'Assessing IT as a Key Success Factor for Accrual Accounting Implementation in Greek Municipalities', Financial Accountability and Management, 23, 1, pp. 91-111.

Cohen, S., Kaimenaki E. and Zorgios, Y., 2007, 'How Different are Accrual Accounting Financial Measures Compared to Cash Accounting ones? Evidence from Greek Municipalities', 6th Annual Conference of the Hellenic Accounting and Finance Association, Patra, December 14-15.

Cohen, S., Kaimenaki, E., Zorgios, Y. and Kaimenakis, N., 2007, 'An Empirical Investigation of Greek Municipalities' Accounting Practices', 6th Annual Conference of the Hellenic Accounting and Finance Association, Patra, December 14-15.

Cohen, S., Kaimenaki E. and Zorgios, Y., 2007, 'Identifying the moderator factors of financial performance in Greek Municipalities', 30th European Accounting Association Annual Congress, Lisbon, April 25-27. 
Coy, D., Tower, G. and Dixon, K., 1994, 'Quantifying the quality of tertiary education annual reports', Accounting and Finance, 33, 2, pp. 121-130.

Comerford, S. and Abernathy, M., 1999, 'Budgeting and management of role conflict in hospitals', Behavioural Research in Accounting, 11, pp. 93-110.

Economou, C. and Giorno, C., 2009, 'Improving the performance of the public health care system in Greece', OECD, Economics department working paper no. 722.

Emsley, D., Nevicky, B. and Harisson, G., 2006, 'Effect of cognitive style and professional development on the initiation of radical and non-radical management accounting innovations', Accounting and Finance, 46, 2, pp. 243-264.

Evans, M., 1995, Resource Accounting and Budgeting in Government: The Policy Framework, Public Finance Foundation, London.

Evans, J.H. and Patton, J.M., 1983, 'An Economic Analysis of Participation in the Municipal Finance Officers Association Certificate of Conformance Program', Journal of Accounting and Economics, 5, 2, pp. 151-175.

Finkelstein, S. and Hambrick, D. C., 1996, 'Strategic leadership: Top Executives and their effects on Organizations', St. Paul MN: West.

Guthrie, J., 1998, 'Application of Accrual Accounting in the Australian Public Sector Rhetoric or Reality?', Financial Accountability \& Management, 14, 1, pp. 1-19.

Giroux, G., 1989, 'Political interests and governmental accounting disclosure', Journal of Accountancy and Public Policy, 8, 3, pp. 199-217.

Hepworth, N., 2003, 'Preconditions for Successful Implementation of Accrual Accounting in Central Government', Public Money and Management, 23, 1, pp. $37-43$.

Hill, N., 2000, Adoption of costing systems in US hospitals: An event history analysis 1980-1990. Journal of Accounting and Public Policy, 19, pp. 41-71.

Hodges, R. and Mellet, H., 2003, 'Reporting public sector financial results', Public Management Review, 5, 1, pp. 99-113.

Hood, C., 1995, 'The New Public Management in the 1980s: Variations on the Theme', Accounting Organizations and Society, 20, 2 \& 3, pp. 93-109.

Ingram, R.W., 1984, 'Economic incentives and the choice of State Government Accounting Practices', Journal of Accounting Research, 22, 1, pp. 126-144.

International Federation of Accountants (IFAC), 2002, Financial reporting by national governments, Public Sector Committee, Study 1, New-York, March 2002.

International Federation of Accountants (IFAC), 2000, Government Financial Reporting: Accounting Issues and Pratices, Public Sector Committee, Study 3, New-York, April 2000.

Jones, R., 1995, Accounts of Government of the U.K., pp. 25-44, International Research in Public Sector Accounting, Reporting and Auditing, Montesinos, V., Vela, J.M. (Ed.), Madrid.

Jones, R. and Pendlebury, M., 1991, 'The published accounts of local authorities, revisited', Financial Accountability and Management, 7, 1, pp. 15-33. 
Krumwiede K., 1998, 'The implementation stages of activity-based costing and the impact of contextual and organizational factors', Journal of Management Accounting Research, 10, pp. 239-277.

Kurunmaki L., Lapsley, I., Melia, K., 2003, 'Accountingization v. legitimation: a comparative study of the use of accounting information in intensive care', Management Accounting Research, 14, pp. 112-139.

Kwon, T. and Zmud, R., 1987, Unifying the fragmented models of informations systems implementation. In R. J. Boland and R. Hirschiem (Eds.), Critical issues in informations systems research. New York: John Wiley.

Lapsley, I., 1988, 'Capital Budgeting, Public Sector Organizations and UK Government Policy', Journal of Accounting and Public Policy, 7, pp. 65-74.

Lapsley, I. and Pallot, J., 2000, 'Accounting, Management and Organizational Change: A Comparative Study of Local Government', Management Accounting Research, 11,2 , pp. 213-29.

Lapsley, I. and Oldfield, R., 2001, 'Transforming the public sector: management consultants as agents of change', The European Accounting Review, 10, 3, pp. 523543.

Lapsley, I. and Wright, E., 2004, 'The diffusion of management accounting innovations in the public sector: a research agenda', Management Accounting Research, 15, pp. 355-374.

Lapsley, I., 2001, 'The Accounting-Clinical interface- implementing budgets for hospital doctors', Abacus, 37, 1, pp. 79-109.

Laughlin, R. and Pallot, J., 1998, 'Trends, patterns and influencing factors: some reflections', in Olson, O., Guthrie, J., Humphrey, C. (Eds), Debating International Developments in New Public Financial Management, Cappelen Akademisk Forlag, Oslo, pp. 376-399.

Lawson, R.A., 2005, 'The use of activity based costing in the healthcare industry: 1994 vs 2004', Research in Healthcare Financial Management, 10, 1, pp. 77-95.

Lüder, K. and Jones, R., (eds.), Reforming governmental accounting and budgeting in Europe, Frankfurt: Fachverlag Moderne Wirtschaft, 2003.

Markus, M. L. and Pfeffer, J., 1983, 'Power and the design and implementation of accounting and control systems', Accounting, Organizations and Society, 8, pp. 205-18.

Mellett, H., 2002, 'The Consequences and Causes of Resource Accounting', Critical Perspectives on Accounting, 13, pp. 231-54.

McGowan, A., and Klammer, T., 1997, 'Satisfaction with Activity -Based cost Management Implementation', Journal of Management Accounting Research, 9, pp. 217-237.

Mossialos, E., Alin, S. and Davaki, K., 2005, 'Analysing the Greek health system: A tale of fragmentation and inertia’, Health Economics, 14, pp. 151-168. 
Naranjo-Gil, D. and Hartman, F., 2007, 'Management accounting systems, Top Management team heterogeneity and strategic change', Accounting, Organizations and Society, 32, pp. 735-756.

Ouda, Hassan, 2008, 'Towards a Generic Model for Government Sector Reform: the New Zealand Experience', International Journal on Governmental Financial Management, 8, 2, pp. 78-100.

OECD, 2003, 'OECD journal of Budgeting', 3, 1, Paris, France.

OECD Health Data 2008, June 2008 (http://www. oecd.org/ health/healthdata)

Pallot, J., 2001, 'Transparency in local government, Antipodean initiatives', The Eurospean accounting review, 10, 3, pp. 645-660.

Pavlatos, O. and Paggios, I., 2009, 'Management Accounting practices in the Greek hospitality industry', Managerial Auditing Journal, 25, 1, pp. 81-98.

Pettersen, I. J., 2001, 'Implementing Management Accounting Reforms in the Public Sector: The Difficult Journey from Intentions to Effects', European Accounting Review, 10, 3, pp. 561-81.

Pessina and Steccolini, I., 2007, 'Effects of budgetary and accruals accounting coexistence: evidence from Italian local governments', Financial Accountability \& Management, 23, 2, pp. 0267-4424.

Pollitt, C., 2002, 'The New Public Management in International Perspective; an Analysis of Impacts and Effects', in K. Mc Laughlin, S.T. Osborne and Ferlie, E. (eds.), New public management, The current trends and future prospects (Routledge), pp. 274-92.

Presidential Decree 146/03, Sectoral Accounting Plan for the Organisations of the Public Health Sector (2003).

Rakoto, H., 2008, 'Contingency Factors Affecting the Adoption of Accrual Accounting in Malagasy Municipalities', International Journal on Governmental Financial Management, 8, 1, pp. 37-50.

Robbins, W.A. and Austin, K.R., 1986, 'Disclosure quality in governmental financial report: An assessment of the appropriateness of a compound measure', Journal of Accounting Research, 24, 2, pp. 412-421.

Ryan, C., 1998, 'The Introduction of Accrual Reporting Policy in the Australian Public Sector: An Agenda Setting Explanation', Accounting, Auditing and Accountability Journal, 11, 5, pp. 518-539.

Ryan, C., Stanley, T. and Nelson, M., 2002, 'Accountability Disclosures by Queensland Local Government Councils: 1997-1999', Financial Accountability and Management, 18, 3, pp. 261-289.

Scapens, R. W. and Roberts, J., 1993, 'Accounting and control: a case study of resistance to accounting change', Management Accounting Research, 4, 1, pp. 1-32.

Scapens, R. W. and Jazayeri, M., 2003, 'ERP systems and management accounting change: opportunities or impacts? A research note', European Accounting Review, 12, 1, pp. 201-233. 
Shields, M., 1995, 'An empirical analysis of firms' implementation experiences with activity-based costing', Journal of Management Accounting Research (Fall): 148166.

Shields, M. and Young, S.M., 1989, 'A behavioural model for implementing cost management systems', Journal of Cost Management (Winter): 17-27.

Stamatiadis, F., 2009, 'Investigating the Governmental Accounting Reform of Greek National Health System (ESY): Some preliminary Evidence', International Journal on Governmental Financial Management, 9, 2, pp. 73-97.

Venieris, G. and Cohen, S., 2004, 'Accounting Reform in Greek Universities: A slow moving process', Financial Accountability \& Management, 20, 2, pp. 0267-4424.

Venieris, G., Cohen, S. and Sykianakis, N., 2003, 'Accounting Reform in Greek NHS', 26th European Accounting Association Annual Congress, Seville, Spain, 2-4 April.

Udpa, S., 1996, 'Activity-based costing for hospitals'. Health Care Management Review, 21, 3, pp. 82-96.

World Health Organization (WHO), Regional Office for Europe, 2005, Highlights on health in Greece 2005, World Health Organization, 2005, pp. 24-28. 
Appendix

Table 1: Demographic Characteristics of Public Hospitals that participated in the survey

\begin{tabular}{|c|c|}
\hline & Number of Hospitals \\
\hline \multicolumn{2}{|l|}{ Geographical Area $(N=94)$} \\
\hline Attica - Piraeus - Aegean & 34 \\
\hline Macedonia \& Thrace & 23 \\
\hline Thessalia & 9 \\
\hline Peloponnese - Ionian Islands - Western Greece & 23 \\
\hline Crete & 5 \\
\hline Total & 94 \\
\hline \multicolumn{2}{|l|}{ Financial Turnover ( $€$ thous.) $(N=94)$} \\
\hline Up to 3.000 & 25 \\
\hline $3.000-15.000$ & 26 \\
\hline $15.000-30.000$ & 10 \\
\hline $30.000-50.000$ & 4 \\
\hline Over 50.000 & 29 \\
\hline Total & 94 \\
\hline \multicolumn{2}{|l|}{ Size - No of beds $(N=94)$} \\
\hline Up to 200 & 39 \\
\hline $200-500$ & 31 \\
\hline Over 500 & 24 \\
\hline Total & 94 \\
\hline \multicolumn{2}{|l|}{ Number of employees $(N=94)$} \\
\hline Up to 100 & 17 \\
\hline $100-400$ & 22 \\
\hline $400-700$ & 22 \\
\hline Over 700 & 33 \\
\hline Total & 94 \\
\hline \multicolumn{2}{|l|}{ Type of hospital Organization $(N=94)$} \\
\hline General hospitals & 76 \\
\hline Specialized hospitals & 18 \\
\hline Total & 94 \\
\hline
\end{tabular}


Table 2: Descriptive statistics for dependent variable (compliance index)

\begin{tabular}{|c|c|c|c|c|c|}
\hline $\begin{array}{l}\text { Compliance } \\
\text { Index }^{\mathrm{a}}\end{array}$ & $\begin{array}{l}\text { Cronbach's } \\
\text { Alfa }^{\text {b }}\end{array}$ & Mean & Std. Dev. & $\begin{array}{l}\text { Minimum } \\
\text { score }\end{array}$ & $\begin{array}{l}\text { Maximum } \\
\text { score }\end{array}$ \\
\hline C & 0.788 & 8.16 & 3.502 & 1 & 14 \\
\hline $\mathrm{C}(\%)$ & & $50.99 \%$ & 21.880 & $6.25 \%$ & $87.50 \%$ \\
\hline \multicolumn{2}{|l|}{ Components } & Mean & Std. Dev. & $\begin{array}{l}\text { Minimum } \\
\text { score }\end{array}$ & $\begin{array}{l}\text { Maximum } \\
\text { score }\end{array}$ \\
\hline \multicolumn{2}{|c|}{$\begin{array}{l}\text { Accurate valuation of } \\
\text { investments }\end{array}$} & 0.53 & 0.502 & $\mathbf{0}$ & 1 \\
\hline \multicolumn{2}{|c|}{ Treatment of provisions } & 0.52 & 0.502 & $\mathbf{0}$ & 1 \\
\hline \multicolumn{2}{|c|}{$\begin{array}{l}\text { Accurate valuation of accounts } \\
\text { receivables }\end{array}$} & 0.64 & 0.483 & $\mathbf{0}$ & 1 \\
\hline \multicolumn{2}{|c|}{ Proper cash account } & 0.88 & 0.323 & $\mathbf{0}$ & 1 \\
\hline \multicolumn{2}{|c|}{ Accurate fixed assets valuation } & 0.49 & 0.503 & $\mathbf{0}$ & 1 \\
\hline \multicolumn{2}{|c|}{ Accurate valuation of liabilities } & 0.72 & 0.450 & $\mathbf{0}$ & 1 \\
\hline \multicolumn{2}{|c|}{ Accurate recognition of revenues } & 0.77 & 0.426 & $\mathbf{0}$ & 1 \\
\hline \multicolumn{2}{|c|}{$\begin{array}{l}\text { Accurate recognition of } \\
\text { expenses }\end{array}$} & 0.79 & 0.411 & $\mathbf{0}$ & 1 \\
\hline \multicolumn{2}{|c|}{$\begin{array}{l}\text { Accurate calculation of assets } \\
\text { depreciation - amortization }\end{array}$} & 0.77 & 0.426 & $\mathbf{0}$ & 1 \\
\hline \multicolumn{2}{|c|}{$\begin{array}{l}\text { Definition of cost centres/pools/ } \\
\text { objects and structure }\end{array}$} & $\mathbf{0 . 3 3}$ & 0.473 & $\mathbf{0}$ & 1 \\
\hline \multicolumn{2}{|c|}{ Proper inventory management } & 0.17 & 0.378 & $\mathbf{0}$ & 1 \\
\hline \multicolumn{2}{|c|}{ Calculation of the cost of capital } & 0.35 & 0.480 & $\mathbf{0}$ & 1 \\
\hline \multicolumn{2}{|c|}{$\begin{array}{l}\text { Short term issuance of financial } \\
\text { accruals statements (trimester } \\
\text { basis) }\end{array}$} & 0.15 & 0.358 & $\mathbf{0}$ & 1 \\
\hline \multicolumn{2}{|c|}{$\begin{array}{l}\text { Accurate calculation of Direct } \\
\text { and indirect cost }\end{array}$} & 0.49 & 0.503 & $\mathbf{0}$ & 1 \\
\hline \multicolumn{2}{|c|}{$\begin{array}{l}\text { Accurate calculation of Fixed } \\
\text { and variable cost }\end{array}$} & 0.36 & 0.483 & $\mathbf{0}$ & 1 \\
\hline \multicolumn{2}{|c|}{$\begin{array}{l}\text { Accurate and updated costing } \\
\text { system }\end{array}$} & 0.20 & 0.404 & $\mathbf{0}$ & 1 \\
\hline
\end{tabular}

${ }^{a}$ It is the overall compliance index that is calculated as the sum of the 16 dichotomous variables that refer to the hospitals' compliance with reformed accounting legislation requirements of P.D. $146 / 03$.

${ }^{\mathrm{b}}$ According to Hair (1998) if the variables being tested are all dichotomous, Cronbach's alpha is the same as Kuder-Richardson coefficient. 
Table 3: Descriptive statistics of the independent variables in the study

\begin{tabular}{|c|c|c|c|c|c|c|}
\hline Variable & Definition & $\begin{array}{l}\text { Mean } \\
\text { value }\end{array}$ & $\begin{array}{c}\text { Std. } \\
\text { Deviation }\end{array}$ & $\begin{array}{l}\text { Actual } \\
\text { Mini- } \\
\text { mum } \\
\end{array}$ & $\begin{array}{c}\text { Actual } \\
\text { Maxi- } \\
\text { mum }\end{array}$ & $\begin{array}{l}\text { Num- } \\
\text { ber of } \\
\text { items } \\
\end{array}$ \\
\hline \multicolumn{7}{|c|}{ Panel A : Independent variables based on a single question } \\
\hline EDUC & $\begin{array}{l}\text { The level of education } \\
\text { of Accounting } \\
\text { department staff }\end{array}$ & 0.25 & 0.117 & 0.08 & 0.48 & 1 \\
\hline EXPER & $\begin{array}{l}\text { The level of learning } \\
\text { experience effect }\end{array}$ & 3.77 & 2.112 & 1 & 10 & 1 \\
\hline COST & $\begin{array}{l}\text { The level of } \\
\text { implementation cost }\end{array}$ & 0.30 & 0.460 & 0 & 1 & \\
\hline CEOEDUC & $\begin{array}{l}\text { The level of the } \\
\text { CEO's educational } \\
\text { background (business } \\
\text { orientation) }\end{array}$ & 0.66 & 0.390 & 0 & 1 & 1 \\
\hline SIZE & $\begin{array}{l}\text { The hospital's size } \\
\text { (no. of beds) }\end{array}$ & 368.39 & 302.96 & 40 & 1200 & 1 \\
\hline \multicolumn{7}{|c|}{ Panel B : Independent variables as a result of a factor analysis ${ }^{a}$} \\
\hline CONFLICT & $\begin{array}{l}\text { The level of the } \\
\text { management- } \\
\text { physicians relationship }\end{array}$ & 3.15 & 0.539 & 1.5 & 4.5 & 2 \\
\hline TRAIN & $\begin{array}{l}\text { The level of the } \\
\text { reform-related training }\end{array}$ & 2.41 & 0.831 & 1 & 4.6 & 3 \\
\hline ITQUAL & $\begin{array}{l}\text { The level of existing } \\
\text { information systems } \\
\text { quality }\end{array}$ & 2.62 & 0.888 & 1 & 5 & 4 \\
\hline CONSUL & $\begin{array}{l}\text { The level of } \\
\text { management } \\
\text { consultants } \\
\text { professional support }\end{array}$ & 2.34 & 1.297 & 1 & 5 & 3 \\
\hline
\end{tabular}

\footnotetext{
${ }^{\mathrm{a}}$ Factors extracted using the principle component analysis (rotated solution; eigenvalues all $>1$ ).
} 


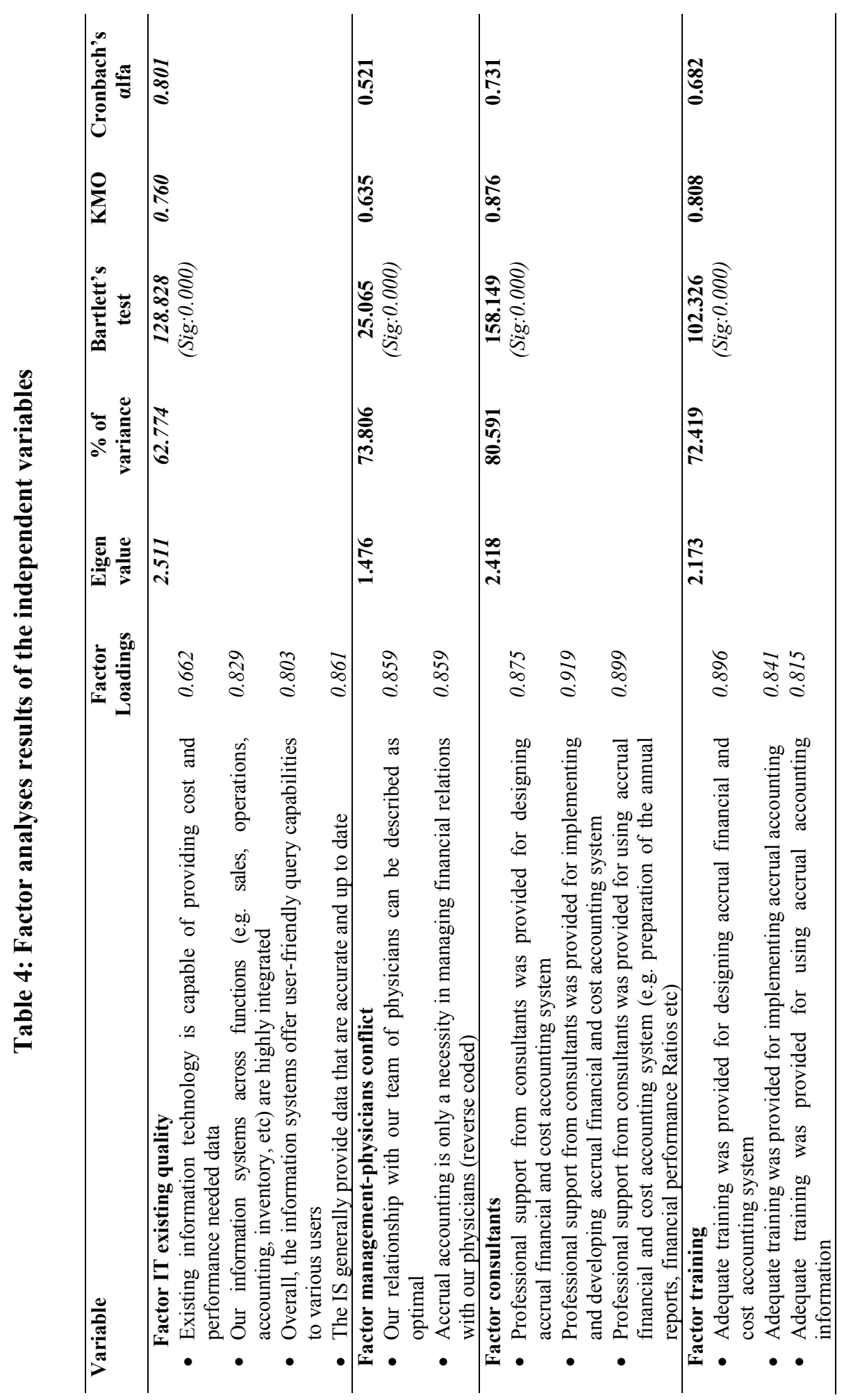




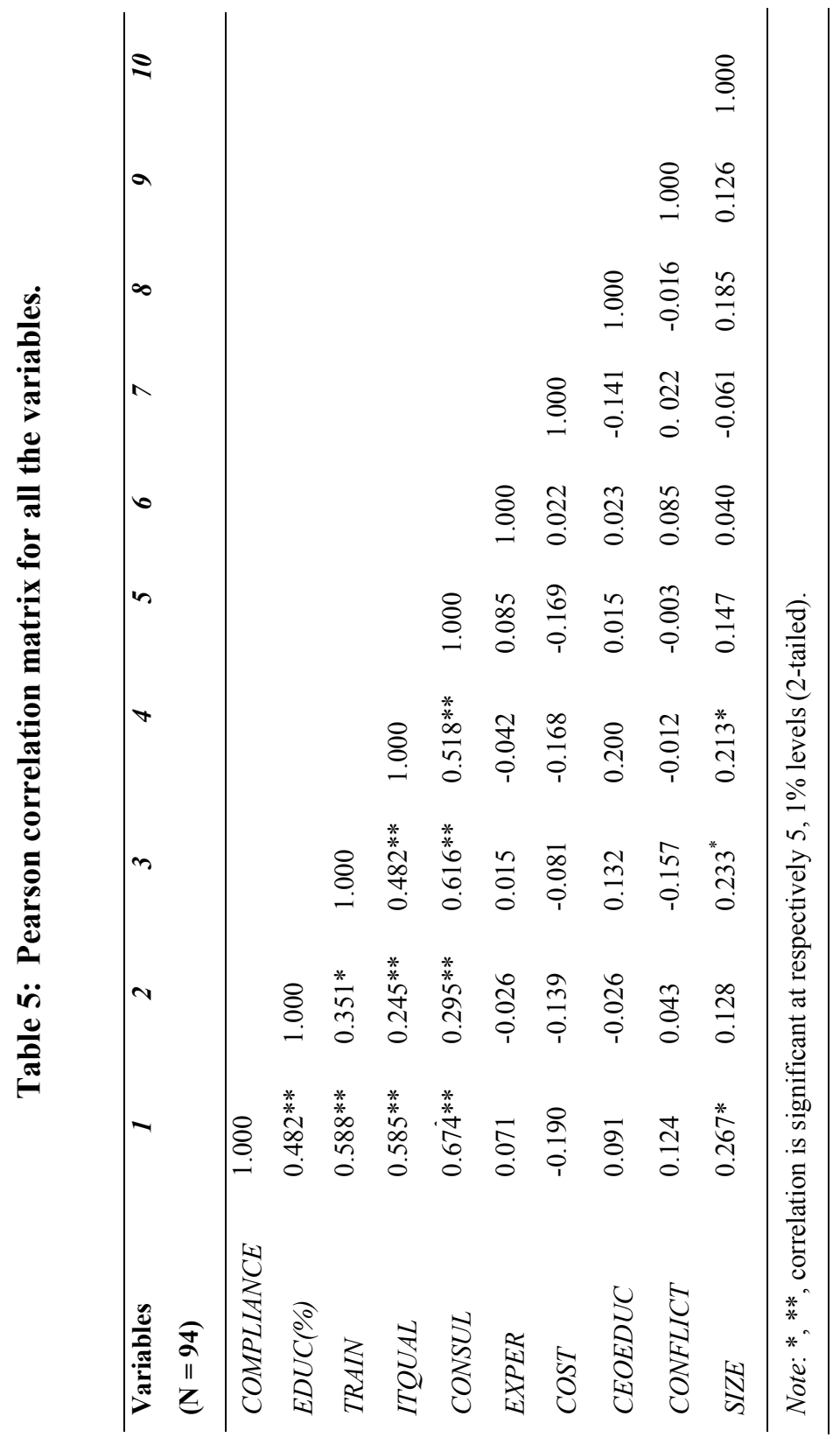


Table 6: Areas of accounting reform compliance vs. non-compliance

\begin{tabular}{|c|c|c|c|}
\hline & & $\begin{array}{c}\text { Number of } \\
\text { Hospitals } \\
\text { that conform to } \\
\text { the accounting } \\
\text { standard } \\
\end{array}$ & $\begin{array}{c}\text { Number of } \\
\text { hospitals that } \\
\text { did not conform to } \\
\text { the accounting } \\
\text { standard } \\
\end{array}$ \\
\hline 1. & Accurate valuation of investments & $50(53.2 \%)$ & $44(46.8 \%)$ \\
\hline 2. & Treatment of provisions & $49(52.1 \%)$ & $45(47.9 \%)$ \\
\hline 3. & $\begin{array}{l}\text { Accurate valuation of accounts } \\
\text { receivables }\end{array}$ & $68(72.3 \%)$ & $26(27.7 \%)$ \\
\hline 4. & Accurate valuation of liabilities & $60(63.8 \%)$ & $34(36.2 \%)$ \\
\hline 5. & Proper cash account Management & $83(88.3 \%)$ & $11(11.7 \%)$ \\
\hline 6. & Accurate fixed assets valuation & $46(48.9 \%)$ & $48(51.1 \%)$ \\
\hline 7. & $\begin{array}{l}\text { Accurate calculation of assets } \\
\text { depreciation - amortization }\end{array}$ & $72(76.6 \%)$ & $22(23.4 \%)$ \\
\hline 8. & Accurate recognition of revenues & $72(76.6 \%)$ & $22(23.4 \%)$ \\
\hline 9. & Accurate recognition of expenses & $74(78.7 \%)$ & $20(21.3 \%)$ \\
\hline 10. & Proper inventory management & $16(17.0 \%)$ & $78(83.3 \%)$ \\
\hline 11. & $\begin{array}{l}\text { Definition of cost centres/pools/ } \\
\text { objects and structure of the cost } \\
\text { accounting system }\end{array}$ & $31(33.0 \%)$ & $63(67.0 \%)$ \\
\hline 12. & Calculation of the cost of capital & $33(35.1 \%)$ & $61(64.9 \%)$ \\
\hline 13. & $\begin{array}{l}\text { Short term issuance of financial } \\
\text { accruals statements (trimester basis) }\end{array}$ & $14(14.9 \%)$ & $80(85.1 \%)$ \\
\hline 14. & $\begin{array}{l}\text { Accurate calculation of Direct and } \\
\text { indirect cost }\end{array}$ & $46(48.9 \%)$ & $48(51.1 \%)$ \\
\hline 15. & $\begin{array}{l}\text { Accurate calculation of Fixed and } \\
\text { variable cost }\end{array}$ & $34(36.2 \%)$ & $60(63.8 \%)$ \\
\hline 16. & $\begin{array}{l}\text { Accurate and updated costing } \\
\text { system }\end{array}$ & $19(20.2 \%)$ & $75(79.8 \%)$ \\
\hline
\end{tabular}


Assessing Accrual Accounting Reform in Greek Public Hospitals:

An Empirical Investigation

Table 7: Multiple regression analysis with the reform accounting compliance as the dependent variable

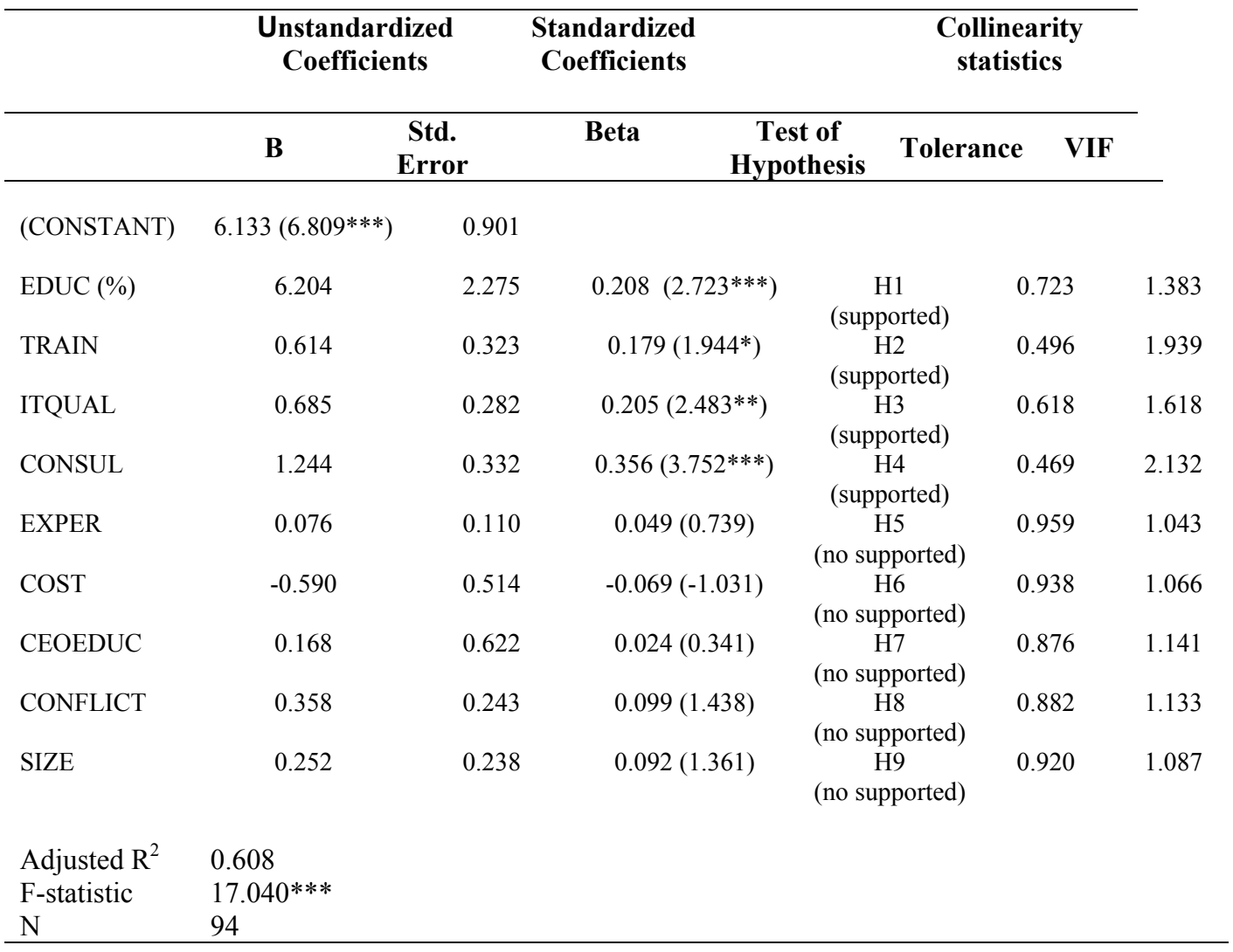

Note: Ordinary least squares coefficients, with corresponding t-statistics in parentheses.

$* * *, * *, *$ indicate statistical significance at the 1,5 and $10 \%$ levels, respectively. 
